\title{
PLASMA VASOPRESSIN LEVELS DURING CARDIOPULMONARY BYPASS WITH AND WITHOUT PROFOUND HAEMODILUTION*
}

\author{
Daniel M. Phildin and Cecil H. Coggins
}

\begin{abstract}
MARKED ELEVATIONS of plasma vasopressin (antidiuretic hormone) levels have been reported in man during cardiopulmonary bypass ${ }^{1,2}$ utilizing profound haemodilution. This resulted in vasopressin levels far beyond the physiological range for an antidiuretic effect on the kidney and in a sodium diuresis. This study was undertaken to determine the effect of the addition of whole blood to the prime on plasma vasopressin $(\mathrm{ADH})$ levels and urinary flow and on electrolyte excretion during cardiopulmonary bypass.
\end{abstract}

\section{METHODS}

Twelve adult male patients scheduled for elective coronary artery bypass operations were selected for study. The average age was 57 years and the type of operation was comparable for all patients. Pre-operative renal function studies were within normal limits. Informed consent was obtained after detailed discussion of the procedure. Premedication consisted of scopolamine $0.4 \mathrm{mg}$ and morphine $0.1 \mathrm{mg} / \mathrm{kg}$ administered intramuscularly approximately one hour before arrival in the induction room.

Each patient had electrocardiogram (ECG) leads placed and a percutaneous radial artery cannula, CVP line and a 16-gauge intravenous line were introduced under local analgesia. Pressures and ECG were recorded continuously on an 8-channel Hewlett Packard monitor with an oscilloscope. A Foley in-dwelling urinary catheter was placed after induction and connected to a collecting bag.

The study was divided into five periods: (1) control, following placement of monitoring lines

Daniel M. Philbin, M.D., Cecil H. Coggins, M.D. Harvard Anaesthesia Research Laboratory, Cardiac Anaesthesia Group and the Department of Medicine at the Massachusetts General Hospital, Boston, Mass., 02114.

*Presented in part at the American Society of Anesthesiologists Annual Meeting. New Orleans, Louisiana, October 1977.

Address all correspondence 10: Daniel M. Philbin, M.D., Department of Anesthesia, Massachusetts General Hospital, Boston, Massachusetts, 02114. prior to induction of anaesthesia; (2) anaesthesia, 15 minutes after induction of anaesthesia and prior to the skin incision; (3) operation, at 15 minutes following skin incision; (4) cardiopulmonary bypass, at 15 and 30 minutes of bypass and during rewarming at $35^{\circ} \mathrm{C} ;(5)$ after bypass, at 15 minutes. During each period, the following variables were measured or recorded: (1) mean arterial and central venous pressures; (2) heart rate and electrocardiogram; (3) arterial blood gases; (4) urine flow; (5) serum and urine osmolality and electrolytes; (6) plasma vasopressin (ADH) levels.

Serum and urine osmolalities were measured by the freezing point depression using a $3 \mathrm{~W}$ advanced osmometer (Advanced Instruments Inc.). Plasma vasopressin levels were determined by radio-immunoassay utilizing Radioactive $\mathrm{I}^{125}$ and rabbit antibodies as previously reported. ${ }^{3}$

After control measurements had been obtained, anaesthesia was induced with thiopentone $2 \mathrm{mg} / \mathrm{kg}$ intravenously while the patients were breathing 0.5 per cent halothane in 50 per cent oxygen-50 per cent nitrous oxide. The trachea was intubated during induction, with relaxation provided by a 0.2 per cent succinylcholine drip and an indwelling Foley bladder catheter was introduced. Measurements were repeated at 15 minutes after induction and again at 15 minutes after skin incision. Prior to the institution of cardiopulmonary bypass patients were divided into two groups according to the wishes of the surgeon: In Group I the bypass prime consisted of 1.5 litres of lactated Ringer's solution and 1.5 litres of whole bank blood. In Group II the bypass prime was 3 litres of lactated Ringer's solution. Measurements were repeated at $15 \mathrm{mi}-$ nutes and 30 minutes during cardiopulmonary bypass while halothane 0.5 per cent was administered through the pump and core temperature was $28^{\circ} \mathrm{C}$. Measurements were repeated during the rewarming period at $35^{\circ} \mathrm{C}$ and again at 15 minutes following cessation of cardiopulmonary bypass with 0.5 per cent halothane being administered in oxygen.

Intragroup data were analyzed for significance 
TABLE I

BLOOD GROUP*

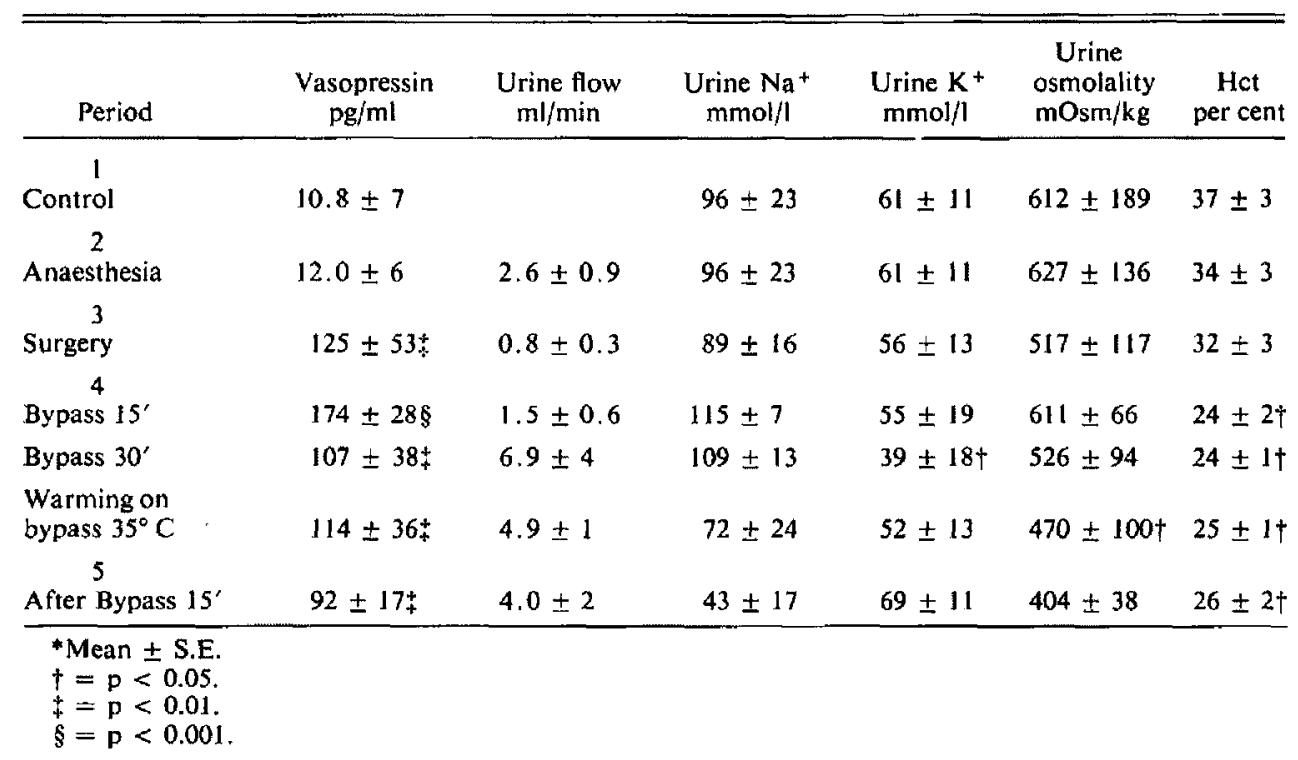

utilizing a paired comparison (correlated t test) and inter-group data utilizing an uncorrelated $t$ test with $\mathrm{p}<0.05$ being considered significant.

\section{RESULTS}

There were no significant changes in serum osmolality or electrolytes in either group throughout the period of the study.

\section{Group I (Blood Prime)}

Table I summarizes the major data for Group I. The changes in urine flow and $\mathrm{Na}^{+}$content were not statistically significant. The decline in urinary $\mathrm{K}^{+}$and osmolality did achieve significance during bypass $(p<0.05)$ as did the fall in haematocrit ( $p$ $<0.05$ ). Plasma vasopressin levels were not significantly elevated until the surgical incisions had been made ( $p<0.01)$ and were further elevated during bypass $(\mathrm{p}<0.001)$.

\section{Group /I (No Blood)}

Table II summarizes the data for Group II. Again the changes in urinary flow in the group did not achieve significance. The decrease in urinary $\mathrm{K}^{+}$and osmolality were statistically significant ( $\mathrm{p}$ $<0.05$ ) during bypass as were the increases in urine $\mathrm{Na}^{+}$. Haematocrit also fell during bypass ( $p$ $<0.01$ ). Again plasma vasopressin levels were significantly elevated during operation $(p<0.01)$ and bypass $(\mathrm{p}<0.001)$ but not during the initial period of anaesthesia alone.

The differences between the two groups for urinary flow and plasma vasopressin levels were not significant. The increase in urinary $\mathrm{Na}^{+}$and the decrease in urinary $\mathrm{K}^{+}$was greater in Group II than Group I $(p<0.05)$ as was the decline in haematocrit for Group II over Group I ( $p<0.01$ ). The figure illustrates graphically some of the major points.

\section{Discussion}

Since the Foley catheter was not inserted until the induction of anaesthesia, no control urine flows could be calculated. Control urine electrolytes and osmolality are reported on the initial sample.

In previous work, we have demonstrated that hatothane-nitrous oxide anaesthesia does not significantly effect plasma vasopressin levels in cardiac surgical patients. ${ }^{4}$ The lack of significant response in these patients following induction of anaesthesia confirms that observation. The vasopressin response to surgical stimulation demonstrated by these patients is also in agreement with the reports in the literatures but the actual levels are somewhat higher.

The marked elevation of plasma vasopressin levels during cardiopulmonary bypass in both of 
TABLE II

No BLOOD GROUP*

\begin{tabular}{|c|c|c|c|c|c|c|}
\hline Period & $\begin{array}{l}\text { Vasopressin } \\
\mathrm{pg} / \mathrm{ml}\end{array}$ & $\begin{array}{c}\text { Urine flow } \\
\mathrm{ml} / \mathrm{min}\end{array}$ & $\begin{array}{c}\text { Urine } \mathrm{Na}^{+} \\
\mathrm{mmol} / \mathrm{l}\end{array}$ & $\begin{array}{l}\text { Urine } \mathrm{K}^{+} \\
\mathrm{mmol} / \mathrm{l}\end{array}$ & $\begin{array}{l}\text { Urine } \\
\text { osmolality } \\
\text { mOsm } / \mathrm{kg}\end{array}$ & $\begin{array}{c}\text { Hot } \\
\text { percent }\end{array}$ \\
\hline $\begin{array}{c}1 \\
\text { Control }\end{array}$ & $7.3 \pm 3$ & & $61 \pm 8$ & $54 \pm 18$ & $572 \pm 82$ & $35 \pm 2$ \\
\hline $\begin{array}{c}2 \\
\text { Anaesthesia }\end{array}$ & $12.0 \pm 5$ & $1.6 \pm 0.8$ & $60 \pm 10$ & $54 \pm 17$ & $528 \pm 80$ & $31 \pm 2$ \\
\hline $\begin{array}{c}3 \\
\text { Surgery }\end{array}$ & $106 \pm 21 *$ & $2.0 \pm 1$ & $71 \pm 17$ & $50 \pm 17$ & $499 \pm 76$ & $28 \pm 1$ \\
\hline $\begin{array}{c}4 \\
\text { Bypass } 15^{\prime}\end{array}$ & $177 \pm 298$ & $4.1 \pm 1.3$ & $120 \pm 11 \dagger$ & $42 \pm 12$ & $466 \pm 46$ & $17 \pm 1+$ \\
\hline $\begin{array}{l}\text { Bypass } 30^{\prime} \\
\text { Warming }\end{array}$ & $147 \pm 31_{4}^{*}$ & $6.4 \pm 4$ & $127 \pm 4 \uparrow$ & $20 \pm 2 \dagger$ & $356 \pm 27 \dagger$ & $18 \pm 1+$ \\
\hline $35^{\circ} \mathrm{C}$ & $141 \pm 28_{t}^{+}$ & $3.1 \pm 1$ & $112 \pm 8$ & $40 \pm 6$ & $372 \pm 53$ & $18 \pm 1 \neq$ \\
\hline$\stackrel{5}{\text { After Bypass } 15^{\circ}}$ & $112 \pm 23 t$ & $4.0 \pm 2$ & $88 \pm 10$ & $60 \pm 12$ & $361 \pm 29$ & $20 \pm 1+$ \\
\hline
\end{tabular}

* Mean + S.E.

$t=p<0.05$.

$\ddagger=\mathrm{p}<0.01$.

$\S=\mathrm{p}<0.001$.

these groups of patients is considerably higher than previously reported ${ }^{1.7}$ and are, indeed, among the highest levels reported in man. This may be partially a reflection of the relatively

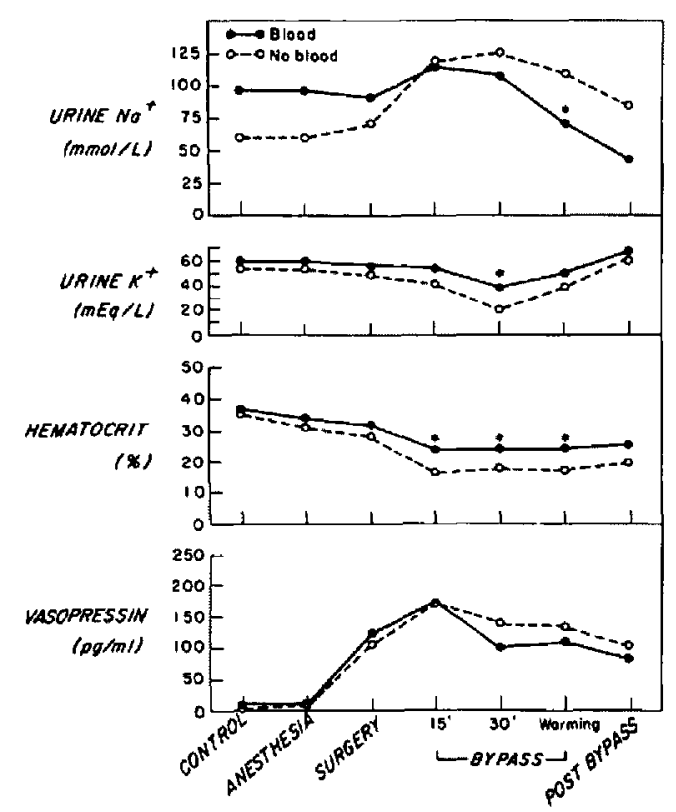

FIgURE 1 Graphic illustration of changes during bypass. Note that the vasopressin levels were almost identical while the differences in urinary electrolytes and haematocrit were significant.

*Significant. "light" anaesthesia and occurred despite the large fluid load and the declining urine osmolality, which would lead one to anticipate a decrease in vasopressin. It is unlikely that the clearance and breakdown of vasopressin, which can be retarded in the hypothermic anaesthetized patient ${ }^{\mathrm{B}}$ would be sufficient to lead to such an accumulation in plasma. If such were the case, rewarming and removal from cardiopulmonary bypass should result in a dramatic decline, which did not occur.

It would appear that introduction of the unphysiological state of cardiopulmonary bypass produces a marked stress response which results in an outpouring of vasopressin. These data indicate that the degree of haemodilution does not appear to be a significant factor, since comparable responses were obtained in both groups.

The loss of pulsatile flow and the rapid decline in left atrial pressure may be more significant factors in the vasopressin release, perhaps in an effort to maintain peripheral vascular resistance. Vasopressin is a potent vasoconstrictor ${ }^{9}$ with a direct action on the smooth muscle of the vasular bed. ${ }^{\prime 0}$ Under these circumstances, there is no correlation between vasopressin levels and urinary flow. These vasopressin concentrations are considerably beyond the physiological range for an antidiuretic effect on the kidney ${ }^{\prime \prime}$ and urine flow may be reflecting the status of haemodynamic events. ${ }^{1}$

These data suggest that the degree of haemodilution may affect urinary electrolyte 
excretion during cardiopulmonary bypass. The increase in urinary $\mathrm{Na}^{+}$content and decrease in urinary $\mathrm{K}^{+}$was significantly greater in Group II than in Group I. During this period serum $\mathrm{Na}^{+}$ was unchanged in either group, suggesting that an electrolyte shift had occurred which was affected by the degree of haemodilution. This would appear to be unrelated to the vasopressin levels or urinary flow.

We conclude from this study that the introduction of cardiopulmonary bypass results in maximal release of vasopressin. This is most likely due to a stress response over-riding the usual osmotic control and is apparently unielated to the degree of haemodilution. The addition of whole blood to the prime would appear to decrease the degree of electrolyte shifts during bypass, resulting in less $\mathrm{Na}^{+}$excretion, but does not significantly affect either urine flow or vaspressin response.

\section{SUMmarY}

In cardiopulmonary bypass the effect on plasma vasopressin levels of the addition of whole blood to the pump priming solution was measured. Six patients (Group I) had blood added to the lactated Ringer's solution for the prime, and six patients (Group II) had only lactated Ringer's solution. Neither group had significant changes in plasma vasopressin levels until surgical stimulation occurred. Comparable significant elevations occurred during bypass in both groups. Greater decreases in haematocrit and urinary $\mathrm{K}^{+}$and greater increases in urinary $\mathrm{Na}^{+}$ occurred in Group II. The degree of haemodilution does not appear to effect plasma vasopressin levels but may alter the degree of electrolyte shift.

\section{RÉSUMÉ}

Les douze malades soumis à cette étude ont été anesthésiés à l'halothane ( 0.5 pour cent) avec protoxyde d'azote et oxygène ( 50 pour cent), pour chirurgie cardiaque élective. L'on a mesuré le taux plasmatiques de vasopressine, avant et après le début de l'anesthésie, durant l'intervention, durant la CEC et immédiatement après celle-ci. Chez six malades (groupe I), l'amorce de la perfusion consistait en un mélange de $1500 \mathrm{ml}$ de sang de banque entier et de $1500 \mathrm{ml}$ de lactate Ringer. Dans les six autres cas, on a utilisé une amorce claire totale, à savoir trois litres de lactate Ringer.

Nous avons retrouvé chez les deux groupes une élévation significative des taux plasmatiques de vasopressine durant l'intervention $(10.8 \pm 7$ à $125 \pm 53 \mathrm{pg} / \mathrm{ml}-\mathrm{p}<0.01$, chez les patients du groupe I) $(7.3 \pm 3$ à $106 \pm 21 \mathrm{pg} / \mathrm{ml}-\mathrm{p}<0.01 \mathrm{chez}$ les patients du groupe 1I), ainsi que durant la circulation extracorporelle (groupe I: $175 \pm 28$ $\mathrm{pg} / \mathrm{ml}-\mathrm{p}<0.001$ et groupe II: $177 \pm 29 \mathrm{pg} / \mathrm{ml}$ ); la différence entre les deux groupes n'est pas significative.

L'hématocrite était plus basse chez les malades du groupe II que chez ceux du groupe I durant la CEC ( $17 \pm 1$ pour cent vs $24 \pm 2$ pour cent). De mème, durant la CEC, le sodium urinaire était plus élevé et le potassium urinaire plus élevé chez les malades du groupe II que chez ceux du groupe I.

Ces résultats indiquent: (1) qu'une anesthésie légère à l'halothane-protoxyde-oxygène ne modifie pas de façon significative les taux plasmatiques de vasopressine; (2) que l'addition de sang total à l'amorce de la CEC ne diminue pas le taux de vasopressine durant la CEC; et (3) qu'une hémodilution marquée peut produire de plus grands changements électrolytiques.

\section{REFERENCES}

1. Philbin, D.M., Coggins, C.H., Wil.son, N., \& Sokoloskı, J. Antidiuretic hormone levels during cardiopulmonary bypass. J. Thorac. and Cardiovasc. Surg. 73: 145 (1977).

2. Wu, W. \& ZBuzkova, V. Plasma vasopressin levels during cardiac surgery. A.S.A. Abstracts of Scientific Papers p. 585 (1977).

3. Philbin, D.M., Wilson, N.E., Sokoloski, J., \& Coggins, C. Radioimmunoassay of antidiuretic hormone during morphine anaesthesia. Canad. Anaesth. Soc. J. 23: 290 (1976).

4. Philbin, D.M. \& Coggins, C.H. Plasma antidiuretic hormone levels in cardiac surgical patients during morphine and halothane anesthesia. Anesthesiology: In Press.

5. UKal, M., Moran, W.H., JR., \& Zimmerman, B. The role of visceral afferent pathways on vasopressin secretion and urinary excretory patterns during surgical stress. Annals of Surgery 168: 16 (1968).

6. Oyama, T.\& Kimura, K. Plasma levels of antidiuretic hormone in man during diethyl-ether anaesthesia and surgery. Canad. Anaesth. Soc. J. 17: $495(1970)$.

7. Soliman, M.G. \& Brindle, G.F. Plasma levels of antidiuretic hormone during and after heart surgery with extra corporeal circulation. Canad. Anaesth. Soc. J. 21: 195 (1974).

8. LANSON, H.D. Metabolism of antidiuretic hormone. Am. J. Med. 42: 713 (1967).

9. Corliss, R.J., MCKenna, D.H., SAller, S. el al. Systemic and coronary hemodynamic effects of vasopressin. Am. J. Med. Sci. 256: 293 (1968).

10. EDmunds, R. \& WEST, J.B. A study on the effect of vasopressin on portal and systemic blood pressure. Surg. Gynecol and Obstet. 114: 458 (1962).

11. Robertson, G.L. Vasopressin in osmotic regulation in man. Ann. Rev. Med. $25: 315$ (1974). 